\title{
TINJAUAN TERHADAP PELANGGARAN KODE ETIK JABATAN NOTARIS DI KABUPATEN PURBALINGGA
}

\author{
Yogi Priyambodo*, Gunarto* \\ * Mahasiswa Program Magister (S2) Kenotariatan Fakultas Hukum UNISSULA, Semarang, e-mail: \\ trafalgargie@yahoo.co.id \\ ** Dosen Fakultas Hukum UNISSULA, Semarang email: gunarto@unissula.ac.id
}

\begin{abstract}
An insufficient Notary only owning membership of law but also have to base on responsibility and carrying out of to be august of ethics and prestige. Role and of Notary of vital importance to traffic punish in society, therefore Notary have to earn to run its profession professionally have, high dedication to and also always hold high standing and its prestige by upholding code of ethics Notary. So that can run its duty better as steward of society, a professional have to run its occupation by harmonizing among owned membership by respect code of ethics profession. Ethics is norms, rules and conditions, which must fulfill by a group of one who is conceived of by circle of professional. Therefore, of vital importance to all Notaries to be able to more comprehend of that deed can be told as collision of code of profession. Ethics, how organizational effectiveness Notary Indonesia in giving construction to all Notaries in order not to happen things which harming Notary and served society it.

Pursuant to the things hence problems to check in this research: A Violations code of ethics, barriers and solutions Violations of code of conduct, as well as the legal consequences violations of the code of ethics by notary in district Purbalingga.

Approach method the used is approach of empirical yuridis and specification of which is used in this research have the character of analytical descriptive research.

Pursuant to result of research can be concluded supervisory council area district Purbalingga which acts as watching and collecting facts about the society and finding relations to violation and board of trustees having authority fall of sanctions to offenders, barriers experienced in the form of inadequate infrastructure, while the legal consequences about moral judgment and ethics Notary itself.
\end{abstract}

Keywords : Violation, Code of Ethics

\section{PENDAHULUAN}

Notaris menurut Pasal 1 angka 1 UndangUndang Nomor 2 Tahun 2014 tentang Perubahan Atas Undang-Undang Nomor 30 Tahun 2004 tentang Jabatan Notaris adalah pejabat umum yang berwenang untuk membuat akta otentik dan memiliki kewenangan lainnya sebagaimana dimaksud dalam undang-undang ini atau berdasarkan undang-undang lainnya. Sebagai pejabat umum yang menjalankan fungsi sosial untuk membuat akta otentik berdasarkan permohonan penghadap atau masyarakat yang membutuhkan jasa dibidang pembuatan akta, seorang notaris dapat dibebani tanggung jawab perbuatannya sehubungan dengan pekerjaannya dalam membuat akta tersebut. Ruang lingkup pertanggung jawaban Notaris meliputi kebenaran materiil atas akta yang dibuatnya. Mengenai tanggung jawab Notaris selaku pejabat umum yang berhubungan dengan kebenaran materiil, Nico membedakannya menjadi empat, yaitu: ${ }^{1}$

1. Tanggung jawab Notaris secara perdata terhadap kebenaran materiil terhadap akta yang dibuatnya;

2. Tanggung jawab Notaris secara pidana terhadap kebenaran materiil terhadap akta yang dibuatnya;

3. Tanggung jawab Notaris berdasarkan Peraturan Jabatan Notaris terhadap kebenaran materiil terhadap akta yang dibuatnya;

4. Tanggung jawab Notaris dalam menjalankan tugas jabatannya berdasarkan kode etik Notaris.

Seorang notaris dalam melaksanakan tugas jabatannya dituntut bertindak jujur dan adil bagi semua pihak, tidak semata-mata untuk kepentingan pribadi, melainkan juga untuk kepentingan

1 Abdul Ghofur Anshori, "Lembaga Kenotariatan Indonesia, Prespektif Hukum dan Etika", (Yogyakarta : UII Press, 2009), h. 34 
masyarakat, serta mempunyai kewajiban untuk menjamin kebenaran akta-akta yang dibuatnya. Oleh karena itu, dalam menjalankan tugas jabatannya, notaris wajib berada dalam pengawasan suatu lembaga yang netral dan mandiri atau independen. Tujuan dari pengawasan terhadap Notaris adalah agar para notaris sungguh-sungguh memenuhi persyaratan-persyaratan dan menjalankan tugas jabatannya sesuai dengan ketentuan-ketentuan dalam peraturan perundang-undangan yang berlaku dan Kode Etik Notaris demi pengamanan dari kepentingan masyarakat umum. Tujuan dari dibuatnya kode etik, dalam hal ini adalah Kode Etik Notaris, pada intinya adalah untuk menjaga kehormatan dan keluhuran martabat jabatan Notaris. $^{2}$

Kedudukan Kode Etik bagi Notaris, yang pertama karena sifat dan hakekat dari pekerjaan Notaris yang sangat berorientasi pada legalisasi, sehingga dapat menjadi fundamen Hukum utama tentang status harta benda, hak dan kewajiban seorang Penghadap yang menggunakan jasa Notaris tersebut. Kedua, agar tidak terjadi ketidakadilan sebagai akibat dari pemberian status harta benda, hak dan kewajiban yang tidak sesuai dengan kaidah dan prinsip-prinsip hukum dan keadilan, sehingga dapat mengacaukan ketertiban umum dan juga mengacaukan hak-hak pribadi dari masyarakat pencari keadilan, maka bagi dunia Notaris sangat diperlukan juga suatu Kode Etik Profesi yang baik dan modern. ${ }^{3}$ Tujuan lainnya dari pengawasan terhadap Notaris adalah guna menjamin pengamanan dari kepentingan umum terhadap para Notaris yang menjalankan jabatannya secara tidak bertanggung jawab dan tidak mengindahkan nilainilai dan ukuran-ukuran etika serta melalaikan keluhuran dari martabat dan tugas jabatannya.

Kode etik profesi Notaris, disusun oleh organisasi profesi Notaris, Ikatan Notaris Indonesia (I.N.I). Pasal 1 angka (2) Kode Etik Notaris Ikatan Notaris Indonesia (I.N.I) menjabarkan bahwa Kode Etik Notaris dan untuk selanjutnya akan disebut kode etik adalah seluruh kaedah moral yang ditentukan

\footnotetext{
${ }^{2}$ Ibid., h. 118

${ }^{3}$ Munir Fuady, "Profesi Mulia (Etika Profesi Hukum bagi Hakim, Jaksa, Advokat, Notaris,

Kurator dan Pengurus)", (Bandung: PT. Citra Aditya Bakti, 2005), h. 133
}

oleh Perkumpulan Ikatan Notaris Indonesia yang selanjutnya akan disebut "Perkumpulan" berdasarkan keputusan Kongres Perkumpulan dan/atau yang ditentukan oleh dan diatur dalam peraturan Perundang-Undangan yang mengatur tentang hal itu dan berlaku bagi serta wajib ditaati oleh setiap dan semua anggota perkumpulan dan semua orang yang menjalankan tugas jabatan sebagai Notaris, termasuk di dalamnya para Pejabat Sementara Notaris, Notaris Pengganti dan Notaris Pengganti Khusus. Kode etik Notaris merupakan seluruh kaedah moral yang menjadi pedoman dalam menjalankan jabatan notaris, memuat kewajiban, larangan dan pengecualian bagi notaris dalam pelaksanaan jabatannya.

Berkaitan dengan hal demikian, maka notaris diminta agar dapat menjalankan profesinya dengan profesional, dengan motivasi dan orientasi pada keterampilan intelektual serta berargumentasi secara rasional dan kritis serta menjunjung tinggi nilai-nilai moral. Berdasarkan hal tersebut di atas, penulis akan membahas lebih lanjut mengenai pelanggaran Kode Etik Notaris di Kabupaten Purbalingga, dengan fokus kajian tentang "Tinjauan Terhadap Pelanggaran Kode Etik Jabatan Notaris Di Kabupaten Purbalingga". Rumusan masalah dalam tulisan ini yakni bagaimana bentuk-bentuk pelanggaran terhadap kode etik oleh notaris di Kabupaten Purbalingga, apa hambatan dan solusi penyelesaian pelanggaran kode etik oleh notaris yang terjadi di Kabupaten Purbalingga, dan apa akibat hukum pelanggaran kode etik oleh notaris yang terjadi di Kabupaten Purbalingga.

\section{METODE PENELITIAN}

Penelitian tesis ini merupakan penelitian dengan menggunakan pendekatan yuridis-empiris, yakni mengutamakan kepada penelitian di lapangan untuk memperoleh data primer, lalu dilengkapi dengan melakukan penelitian kepustakaan untuk memperoleh data sekunder. Hasil dari penelitian ditampilkan dalam bentuk laporan yang bersifat deskriptif analitis, yakni memaparkan, menggambarkan atau mengungkapkan sanksi kode etik terhadap pelanggaran jabatan oleh notaris di Kabupaten Purbalingga.

Data yang dikumpulkan dalam penelitian ini adalah data primer yang diperoleh melalui wawancara terhadap beberapa responden sebagai 
sampel penelitian dan data sekunder diperoleh dengan cara studi / kajian pustaka. Responden dipilih menggunakan teknik penarikan sampel purposivenon random sampling, diantaranya adalah : anggota Majelis Pengawas Daerah (MPD) Kabuapten Purbalingga sebanyak 1 orang, Notaris dengan tahun kerja 1990-2000 sebanyak 1 orang, Notaris dengan tahun kerja 2001-2010 sebanyak 2 orang, dan Notaris dengan tahun kerja 2010-sekarang sebanyak 2 orang.

\section{HASIL PENELITIAN DAN PEMBAHASAN}

\section{Bentuk-bentuk Pelanggaran Terhadap Kode Etik oleh Notaris Di Kabupaten Purbalingga}

Notaris merupakan suatu profesi hukum yang sangat penting dalam sistem hukum, mengingat notaris merupakan pejabat umum yang berwenang untuk membuat suatu akta otentik. Dengan demikian dapat dikatakan bahwa notaris adalah salah satu pilar penegakan hukum di Indonesia. Dalam menjalankan jabatannya sebagai pejabat umum, notaris harus senantiasa berpedoman pada UndangUndang Jabatan Notaris dan Kode Etik Notaris. Dalam Pasal 15 Undang-Undang Nomor 2 Tahun 2014 Tentang Jabatan Notaris, dapat diketahui tugas dan kewenangan seorang Notaris yaitu membuat Akta otentik. Disamping itu, Notaris juga memberikan nasehat hukum dan penjelasan mengenai peraturan perundang-undangan kepada pihak-pihak yang menghadap kepadanya berkaitan dengan pembuatan suatu Akta. Notaris seyogyanya hidup dan berperilaku baik di dalam menjalankan jabatannya atas dasar nilai, moral dan etik notaris. Mendasarkan pada nilai, moral dan etik notaris, maka hakekat pengembanan profesi jabatan notaris adalah Pelayanan kepada masyarakat (klien) secara mandiri dan tidak memihak. ${ }^{4}$

Sebagai pejabat umum, notaris harus memiliki etika kepribadian notaris, yaitu:

1. Berjiwa Pancasila;

2. Taat kepada hukum, sumpah jabatan notaris, kode etik notaris;

3. Notaris menertibkan diri sesuai dengan fungsi,

4 Hasil Wawancara dengan Notaris Ratnawati.,S.H Notaris Senior Kabupaten Purbalingga, di Purbalingga, Tanggal 1 Agustus 2016 kewenangan, dan kewajiban sebagaimana ditentukan dalam Peraturan Jabatan Notaris;

4. Berbahasa Indonesia yang baik.

Lebih lanjut Ratnawati menjelaskan bahwa notaris harus memiliki perilaku profesional (professional behavior). Unsur-unsur perilaku profesional adalah sebagai berikut :

1. Memiliki perilaku profesional ;

2. Ikut serta pembangunan nasional di bidang hukum;

3. Menjunjung tinggi kehormatan dan martabat;

4. Keahlian yang didukung oleh pengetahuan dan pengalaman tinggi;

5. Integritas moral artinya menghindari sesuatu yang tidak baik walaupun imbalan jasanya tinggi, pelaksanaan tugas profesi diselaraskan dengan nilai-nilai kemasyarakatan, sopan santun, dan agama;

6. Jujur tidak saja pada pihak kedua atau pihak ketiga, tetapi juga pada diri sendiri;

7. Tidak semata-mata pertimbangan uang, melarikan juga pengabdian, tidak membedakan antara orang mampu dan tidak mampu.

8. Berpegang teguh pada kode etik profesi karena didalamnya ditentukan segala perilaku yang harus dimiliki oleh Notaris, termasuk berbahasa Indonesia yang sempurna. ${ }^{5}$

Dalam menjalankan tugas dan jabatannya untuk kepentingan masyarakat umum, notaris wajib berada dalam pengawasan suatu lembaga yang netral dan mandiri atau independen. Pengawasan atas pelaksanaan kode etik dilakukan dengan cara sebagai berikut:

1. Pada tingkat pertama dilakukan oleh pengurus daerah Ikatan Notaris Indonesia dan Dewan Kehormatan Daerah;

2. Pada tingkat banding dilakukan oleh pengurus wilayah Ikatan Notaris Indonesia dan Dewan Kehormatan Wilayah;

3. Pada tingkat akhir dilakukan oleh pengurus pusat Ikatan Notaris Indonesia dan Dewan Kehormatan Pusat.

Majelis Pengawas Daerah (MPD) sifatnya lebih pada memproses kalaupun ada bentuk-bentuk

\footnotetext{
${ }^{5}$ Hasil Wawancara dengan Notaris Ratnawati,S.H Notaris Senior Kabupaten Purbalingga, di Purbalingga, Tanggal 1 Agustus 2016
} 
pelanggaran Kode Etik ada laporan dari masyarakat dan notaris itu sendiri dan bertindak ketika telah terjadi dan sifatnya investigasi tergantung banyaknya laporan yang masuk karena di Kabupaten Purbalingga sendiri Dewan Kehormatan belum dibentuk dan permasalahan pelanggaran Kode Etik tidak menjadi masalah yang berat, sebatas kelalaian dan keteledoran Notaris ${ }^{6}$. Sejak kehadiran institusi Notaris di Indonesia, pengawasan terhadap Notaris selalu dilakukan oleh lembaga peradilan dan pemerintah, bahwa tujuan dari pengawasan agar para Notaris ketika menjalankan tugas dan jabatan Notaris adalah demi untuk pengamanan kepentingan masyarakat, karena Notaris diangkat oleh Pemerintah, bukan untuk kepentingan diri Notaris itu sendiri melainkan untuk kepentingan masyarakat yang dilayaninya. ${ }^{7}$ Tujuan pokok pengawasan adalah agar segala hak dan kewajiban yang diberikan kepada Notaris dalam menjalankan tugasnya sebagaimana diberikan oleh Perundang-Undangan senantiasa dilakukan di atas jalur yang telah ditentukan, bukan saja jalur hukum tetapi juga atas dasar moral dan etika profesi demi terjaminnya perlindungan hukum dan kepastian hukum bagi masyarakat.

Menurut Tajuddin Nasution, SH, seorang Ketua Majelis Pengawas Daerah (MPD) Notaris Kabupaten Purbalingga, dari unsur pemerintah tugas Majelis Pengawas Daerah (MPD) secara kewenangan mempunyai wewenang, sedangkan kinerja Majelis Pengawas Daerah (MPD) melakukan pemeriksaan berkala 1 (satu) tahun sekali apabila terjadi Pelanggaran Kode Etik akan dimuat dalam Berita Acara Pemeriksaan dikirim ke Majelis Pengawas Wilayah (MPW), sebab diketahuinya dari pemeriksaan, adanya laporan dari masyarakat, mengumpulkan fakta yang benar-benar terjadi dan terbukti adanya pelanggaran dan Majelis Pengawas Daerah (MPD) melakukan proses persidangan dengan membentuk tim pemeriksa. Hasilnya dikirim ke Majelis Pengawas Wilayah (MPW), dan melakukan persidangan kembali dan kewenangan sanksi dari Majelis Pengawas Wilayah (MPW) bukan dari Majelis

\footnotetext{
${ }^{6}$ Hasil Wawancara dengan Tajuddin Nasution,S.H Ketua Majelis Pengawas Daerah Notaris Kabupaten Purbalingga, di Purbalingga, Tanggal 2 Agustus 2016

7 G.H.S Lumban Tobing, Peraturan Jabatan Notaris, Cet.5, ( Jakarta: Airlangga, 1999 ), h.301
}

Pengawas Daerah (MPD). ${ }^{8}$ Pelanggaran Kode etik yang terjadi dan diketahui oleh Majelis Pengawas Daerah Notaris Pengurus Daerah Ikatan Notaris Indonesia Kabupaten Purbalingga, antara lain adalah:

1. Memberikan ucapan baik suka ataupun duka, atas dasar Notaris bukan personal yang dilarang oleh Kode Etik Notaris, sekedar mengingatkan saja dari Majelis Pengawas Daerah (MPD) agar tidak melanggar lagi

2. Papan nama Notaris tidak sesuai semestinya, misal: dengan ukuran tidak semestinya, pemberian aksesoris pada papan nama berupa lampu hias, dan warna selain hitam dan putih

3. Laporan masyarakat terkait dengan dugaan pada sifat netral, yakni memihak salah satu pihak klien

4. Terdapatnya pengurusan akta yang belum selesai dan memberitahu kepada klien perihal selesainya

5. Membuat akta dengan waktu yang lama

6. Menahan berkas seseorang dengan maksud agar tidak berpindah Notaris

7. Memberikan blanko kosong kepada klien untuk menandatanganinya, dan klien tidak tahu isi akta tersebut. ${ }^{9}$

Menurut Ratnawati dan Arumi Reni Ratnawati Notaris di Kabupaten Purbalingga, pelanggaran kode etik Notaris merupakan realitas yang banyak terjadi dan tidak dapat dipungkiri dalam prakteknya. Hal ini disebabkan oleh persaingan yang ketat dalam praktek Notaris yang berawal dari makin bertambahnya jumlah Notaris. Kondisi ini akan bertambah buruk dan dilematis oleh karena lemahnya sosialisasi tentang kode etik dan tidak optimalnya pengawasan yang dilakukan oleh organisasi profesi Notaris, dalam hal ini Ikatan Notaris Indonesia. Selain hal tersebut dikalangan Notaris sendiri terdapat perilaku dan persepsi untuk tidak terlalu menghiraukan kode etik Notaris. ${ }^{10}$ Pengawasan terhadap notaris sebenarnya tidak hanya dapat dilakukan oleh organisasi profesi Notaris,

\footnotetext{
${ }^{8}$ Hasil Wawancara dengan Tajuddin Nasution,S.H Ketua Majelis Pengawas Daerah Notaris Kabupaten Purbalingga, di Purbalingga, Tanggal 2 Agustus 2016

${ }^{9}$ Hasil Wawancara dengan Tajuddin Nasution,S.H Ketua Majelis Pengawas Daerah Notaris Kabupaten Purbalingga, di Purbalingga, Tanggal 2 Agustus 2016

${ }^{10}$ Hasil wawancara dengan Ratnawati, S.H dan Arumi Reni Ratnawati., S.H.,M.Kn Notaris Kabupaten Purbalingga tanggal 1 Agustus 2016
} 
tetapi juga oleh masyarakat, dikarenakan pelayanan yang dilakukan Notaris termasuk pada fungsi kemasyarakatan yang langsung berkaitan dengan nilai dasar yang menentukan derajat kemasyarakatan yang berkaitan dengan nilai dasar yang menentukan derajat perwujudan martabat manusia. Namun, masyarakat pada umumnya tidak memiliki kompetensi teknikal untuk dapat menilai dan melakukan pengawasan yang efektif terhadap Notaris. Sehubungan dengan nilai dan kepentingan yang terlibat didalamnya, maka Notaris dalam melaksanakan jabatannya dijiwai sikap etis tertentu yaitu yang dijiwai etika profesi Notaris. Menurut penulis dikarenakan Notaris merupakan profesi yang menjalankan sebagian kekuasaan negara di bidang hukum privat dan mempunyai peran penting dalam membuat akta otentik yang mempunyai kekuatan pembuktian sempurna dan oleh karena jabatan Notaris merupakan jabatan kepercayaan, maka seorang Notaris harus mempunyai perilaku yang baik. Perilaku Notaris yang baik dapat diperoleh dengan berlandaskan pada kode etik Notaris. Dengan demikian, maka kode etik Notaris mengatur mengenai hal-hal yang harus ditaati oleh seorang Notaris dalam menjalankan jabatannya dan juga di luar menjalankan jabatannya.

\section{Hambatan-Hambatan dan Solusi Penyelesaian Pelanggaran Kode Etik Oleh Notaris Yang Terjadi di Kabupaten Kota Purbalingga}

Dalam rangka pembinaan dan pengawasan terhadap Notaris di Kabupaten Purbalingga, upaya yang dilakukan oleh Majelis Pengawas Daerah Kabupaten Purbalingga adalah dengan menerapkan pengawasan yang bersifat preventif dan kuratif, yakni melakukan pencegahan terhadap terjadinya pelanggaran jabatan Notaris dan melakukan pembinaan terhadap Notaris itu sendiri. Dalam melaksanakan pengawasan maupun pembinaan Notaris di Kabupaten Purbalingga yang dilakukan oleh Majelis Pengawas Daerah Kabupaten Purbalingga, pelaksanaannya tidak selalu berjalan lancar sesuai apa yang diatur dalam Undang Undang Jabatan Notaris, Permen, maupun Kepmen tentang Pengawasan Notaris. Adapun kendala-kendala yang dihadapi Majelis Pengawas Daerah Kabupaten Purbalingga dalam melaksanakan fungsi pengawasan menurut hasil wawancara dengan Tajuddin Nasution, $\mathrm{SH}$, selaku Ketua Majelis Pengawas Daerah Notaris Kabupaten Purbalingga, disimpulkan:

1. Keterbatasan dana yang digunakan Majelis Pengawas Daerah Notaris Kabupaten Purbalingga untuk melakukan pembinaan dan pengawasan, karena dana yang seharusnya disediakan oleh Kantor Wilayah Kementerian Hukum dan Hak Asasi Manusia Republik Indonesia Provinsi Jawa Tengah tidak mencukupi

2. Kesibukan masing-masing anggota Majelis Pengawas Daerah Notaris Kabupaten Purbalingga dalam melakukan pekerjaan utamanya yaitu sebagai dosen, sebagai notaris maupun yang bekerja sebagai pegawai negeri sipil di masingmasing instansi terkait

3. Masing-masing anggota Majelis Pengawas Daerah Notaris Kabupaten Purbalingga tidak memiliki visi dan program

4. Kurangnya aturan pelaksana Undang-Undang Jabatan Notaris sehubungan dengan pembinaan dan pengawasan yang dilakukan oleh Majelis Pengawas Notaris

Langkah-Langkah hukum secara konkrit yang dapat dilakukan oleh Majelis Pengawas Daerah Kabupaten Purbalingga untuk memaksimalkan fungsi pembinaan dan pengawasan yaitu dengan menerapkan berbagai bentuk pengawasan yang terdapat dalam teori-teori pengawasan, yaitu diantaranya:

1. Ditinjau dari segi kedudukan badan/organ yang melaksanakan pengawasan, terdiri dari:

a. Pengawasan Intern.

Merupakan Pengawasan yang dilakukan oleh satu badan yang secara organisatoris/struktural masih termasuk dalam lingkungan pemerintahan sendiri. Dalam hal ini karena bidang Notariat masuk pada lingkungan Kementerian Hukum dan Hak Asasi Manusia Republik Indonesia maka Majelis Pengawas Daerah Kabupaten Purbalingga yang didasarkan pada Pasal 67 Ayat (1) dan Ayat (2) UUJN, Pasal 1 Ayat (8) Kepmen Nomor. MOL.H.T.03.01. Tahun 2003, Nomor 3 Bagian Tujuan Kepmen Nomor: M.39-PW.07.10 Tahun 2004, yang terdiri atas:

1) Pengawasan yang dilakukan oleh pemimpin / atasan langsung, baik di tingkat pusat yang dilakukan oleh Majelis Pengawas Pusat (MPP) 
Notaris di Ibukota Negara yang berada langsung dibawah Menteri Hukum dan Hak Asasi Manusia Republik Indonesia, maupun di tingkat wilayah yaitu oleh Majelis Pengawas Wilayah (MPW) Notaris Provinsi Jawa Tengah yang dilaksanakan oleh MPD Notaris Kabupaten Purbalingga.

2) Pengawasan yang dilakukan secara fungsional oleh aparat pengawasan terhadap keuangan negara meliputi:

a) Pengawasan formal, misalnya dalam prosedur keberatan, hak petisi, banding administratif, yang digolongkan menjadi pengawasan prenventif, yaitu keharusan adanya persetujuan dari atasan sebelum keputusan diambil, seperti yang dilakukan oleh Majelis Pengawas Daerah dalam Pasal 70 huruf $f$ dan Pasal 71 huruf e UUJN, dalam bagian ke III Nomor 1.2 Kepmen Nomor: M.39-PW.07.10 Tahun 2004 dan Pengawasan represif seperti penangguhan pelaksanaan secara spontan dan kemungkinan pembatalan

b) Pengawasan informal seperti langkahlangkah evaluasi dan penangguhan ${ }^{11}$

b. Pengawasan Extern

Adalah Pengawasan yang dilakukan oleh organ/ lembaga secara organisatoris/ struktural yang berada diluar pemerintah (eksekutif), misalnya dalam pengawasan yang dilakukan oleh Organisasi Notaris yaitu INI daerah Kabupaten Purbalingga terhadap para Notaris di Kabupaten Purbalingga melalui Dewan Kehormatan Daerah.

2. Pengawasan Preventif dan Represif

Yang dimaksud Pengawasan Preventif yaitu pengawasan yang dilakukan sebelum dikeluarkan suatu keputusan/ketetapan, sehingga bersifat korektif dan memulihkan suatu tindakan yang keliru, disebut juga Pengawasan Aposteriori. ${ }^{12}$ Pengawasan preventif terkait dengan pengawasan terhadap Notaris, antara lain adalah hal-hal yang diatur Pasal 70 Huruf b, c, d, e, f dan h UUJN, Pasal 13 ayat (2) huruf d UUJN, yang mengatur tentang pengambilan tindakan terhadap dugaan-dugaan pelanggaran yang

\footnotetext{
${ }^{11}$ Diana Hakim Koentjoro, op.cit., h.11

${ }^{12}$ Diana Hakim Koentjoro, op.cit., h.11
}

dilakukan oleh Notaris terhadap UUJN dan Kode Etik.

3. Pengawasan dari segi hukum

Pengawasan dari segi hukum merupakan suatu penilaian tentang sah atau tidaknya suatu akta yang telah dibuat oleh Notaris yang menimbulkan akibat hukum. Adapun kewenangan melakukan pengawasan terhadap perbuatan Notaris yang bijaksana maupun tidak, menjadi wewenang dari MPD sesuai dengan Pasal 70 dan Pasal 71 UUJN, Pasal 13 dan Pasal 14 Permen Nomor M.02.PR08.10 Tahun 2004. Tujuan diadakannya pengawasan dari segi hukum, yaitu agar Notaris dalam melakukan tindakannya harus memperhatikan norma-norma Hukum dalam rangka memberi perlindungan hukum bagi masyarakat, yang terdiri dari upaya administratif yang dilaksanakan oleh Majelis Pengawas Daerah, Majelis Pengawas Wilayah, dan Majelis Pengawas Pusat secara berjenjang.

\section{Akibat Hukum Pelanggaran Kode Etik Oleh Notaris yang Terjadi di Kabupaten Purbalingga}

Sebagai pengemban amanat dan kepercayaan masyarakat, Notaris sebagai pejabat umum sudah seharusnya mendapat perlindungan hukum dalam menjalankan jabatannya. Notaris yang diduga melakukan pelanggaran kode etik harus didengar keterangannya terlebih dahulu dan diberi kesempatan untuk membela diri sebelum Dewan Kehormatan Pusat menyampaikan usul pemberhentian sementara kepada Pengurus Pusat. Dalam menangani atau menyelesaikan suatu kasus, anggota Dewan Kehormatan Pusat harus tetap menghormati dan menjunjung tinggi martabat anggota yang bersangkutan, selalu menjaga suasana kekeluargaan dan merahasiakan segala apa yang ditemukannya. Seorang Notaris yang diduga melakukan pelanggaran kode etik hendaknya diberikan advokasi atau pendampingan oleh perkumpulan dengan tetap menjunjung tinggi asas praduga tak bersalah. Terhadap penjatuhan sanksi pemberhentian sementara (schorsing) atau pemecatan (onzetting) dari keanggotaan perkumpulan, Dewan Kehormatan Daerah wajib berkonsultasi terlebih dahulu dengan Pengurus Daerahnya dan seorang Notaris yang telah dijatuhi 
sanksi berupa pemecatan sementara (schorsing) atau pemecatan (onzetting) dari keanggotaan perkumpulan dapat mengajukan/ memohon banding dengan surat tercatat atau dikirim langsung kepada Dewan Kehormatan Wilayah dan tembusannya kepada Dewan Kehormatan Pusat, Pengurus Pusat, Pengurus Wilayah, dan Pengurus Daerah. Setelah permohonan bandingnya diterima, selambatlambatnya dalam waktu tujuh hari kerja Dewan Kehormatan Wilayah memanggil anggota yang naik banding, untuk didengar keterangannya dan diberi kesempatan membela diri dalam sidang Dewan Kehormatan Wilayah dan dalam waktu tiga puluh hari kerja, Dewan Kehormatan Wilayah memberi putusan dalam tingkat banding melalui sidangnya, walaupun anggota yang dipanggil tidak datang Dewan Kehormatan Wilayah, tetap akan memberi putusan dalam waktu yang ditentukan.

Menurut Abdulkadir Muhammad terdapat empat alasan mendasar mengapa profesional termasuk Notaris mengabaikan kode etik. Alasan-alasan tersebut meliputi: pengaruh sifat kekeluargaan; pengaruh jabatan; pengaruh konsumerisme; dan karena lemah iman. ${ }^{13}$ Salah satu syarat menjadi profesional itu adalah taqwa kepada Tuhan Yang Maha Esa, yaitu melaksanakan perintah dan menjauhi larangan-laranganNya. Ketaqwaan adalah dasar moral manusia. Dengan taqwa kepada Tuhan Yang Maha Esa, profesional memiliki benteng moral yang kuat, tidak mudah tergoda dan tergiur dengan beragam macam bentuk materi di sekitarnya. Dengan iman yang kuat kebutuhan akan terpenuhi secara wajar dan itulah kebahagiaan. Selain hal tersebut di atas berdasarkan hasil penelitian di lapangan dapat diketahui bahwa pelanggaran Kode Etik yang terjadi seringkali hanya menjadi isu karena sanksi terhadap pelanggaran tersebut hanya berupa sanksi moral meskipun telah diatur secara tegas dalam Kode Etik Notaris, sehingga data mengenai pelanggaran dalam penerapan Kode Etik hanya sedikit. Pelanggaran Kode Etik yang terjadi akan tetapi hanya menjadi isu tersebut antara lain: terdapat Notaris yang dalam membuat akta tidak membacakan dan menyaksikan penandatanganan akta tersebut dihadapannya sebagai Notaris yang bersangkutan, melainkan dihadapan karyawan kantor

\footnotetext{
${ }^{13}$ Abdulkadir Muhammad, Op. Cit., h. 82-85.
}

Notaris tersebut. Pelanggaran demikian sering terjadi dalam hal Notaris yang melakukan kerja sama dengan Bank dalam pembuatan akta-akta perjanjian kredit. Notaris yang demikian biasanya menawarkan jasa dengan honorarium yang jauh dibawah standar. ${ }^{14}$

\section{PENUTUP}

\section{Simpulan}

Bagi notaris yang melakukan pelanggaran kode etik, Majelis Pengawas Daerah Kabupaten Purbalingga yang bertindak sebagai pengawas dan mengumpulkan fakta tentang laporan dari masyarakat dan temuan terkait pelanggaran, dan Dewan Kehormatan yang mempunyai wewenang dapat menjatuhkan sanksi kepada pelanggarnya. Sanksi yang dikenakan terhadap anggota Ikatan Notaris Indonesia yang melakukan pelanggaran kode etik tersebut dapat berupa : Teguran, Peringatan, Schorzing (pemecatan) dari keanggotaan Perkumpulan, Onzetting (pemecatan) dari keanggotaan Perkumpulan dan Pemberhentian dengan tidak hormat dari keangotaan Perkumpulan. Namun, sanksi pemecatan yang diberikan terhadap Notaris yang melakukan pelanggaran kode etik bukanlah berupa pemecatan dari jabatan Notaris melainkan pemecatan dari keanggotaan Ikatan Notaris Indonesia, sehingga walaupun Notaris yang bersangkutan telah terbukti melakukan pelanggaran kode etik, Notaris tersebut masih dapat membuat akta dan menjalankan kewenangan lainnya sebagai Notaris, karena hanya menteri yang berwenang untuk memecat Notaris dari jabatannya dengan mendengarkan laporan dari Majelis Pengawas. Sehingga sanksi tersebut terkesan kurang mempunyai daya mengikat bagi Notaris yang melakukan pelanggaran kode etik.

Hambatan-hambatan yang terjadi dalam melaksanakan pengawasan Notaris diwilayahnya oleh Majelis Pengawas Daerah (MPD) antara lain:

1. Kurangnya sarana dan prasarana yang memadai

2. Keterbatasan waktu para anggota MPD Kabupaten Purbalingga yang terlalu sibuk dengan pekerjaan atau tugas pokok masing-masing

\footnotetext{
${ }^{14}$ Wawancara Agung Diharto, Notaris dan Ketua INI di Kabupaten Purbalingga, Pada Tanggal 2 Agustus 2016
} 
3. Anggaran dari pemerintah yang terbatas

4. Kurangnya partisipasi masyarakat dalam melaporkan dugaan pelanggaran Notaris karena keterbatasan akses

5. Wilayah kerja MPD Kabupaten Purbalingga yang meliputi seluruh wilayah Kabupaten Purbalingga serta Banyumas yang sangat luas dan jumlah Notaris Kabupaten Purbalingga yang mencapai 16 Notaris, dan masalah belum banyak dan kompleks seperti di kota-kota besar

6. Kurangnya kesadaran hukum beberapa Notaris Kabupaten Purbalingga

7. MPD tidak memiliki wewenang untuk menjatuhkan sanksi terhadap Notaris yang melanggar Undang-Undang Jabatan Notaris

Akibat hukum jika terjadi pelanggaran kode etik oleh Notaris adalah sebagai berikut :

1. Notaris sebagai penyandang dan pengemban jabatan terhormat terlebih sebagai pemegang amanat, apabila telah terjadi pelanggaran dan masih tersisa padanya nilai-nilai luhur yang dimiliki notaris maka hukuman yang dijalani dan dirasa adalah rasa tidak tenang, karena diliputi perasaan bersalah.

2. Pelanggaran oleh notaris terhadap etika profesi yang telah dibukukan atau peraturan-peraturan yang telah disusun secara tertulis dan mengikat serta wajib ditaati oleh segenap anggota kelompok profesi dan dapat dikenakan sanksi bagi yang melanggar ketentuan tersebut.

3. Notaris yang melakukan pelanggaran kode etik sebagaimana ditentukan dalam peraturan perundang-undangan, maka penyelesaiannya berdasarkan ketentuan itu sendiri, sehingga kepastian hukum terhadap profesi Notaris lebih terjamin.

\section{Saran}

1. Notaris diharapkan dalam menjalankan jabatannya selaku pejabat umum yang berwenang dalam pembuat akta otentik, mampu memahami dan melaksanakan ketentuan kode etik Notaris sebagai pedoman dalam melaksanakan profesi Notaris;

2. Agar dapat menjalankan profesinya sesuai dengan tuntutan etika profesi itu, notaris harus memiliki tiga ciri moral, yaitu: harus memiliki kepribadian moral yang kuat; harus sadar bahwa mempertaliankan tuntutan etika profesi merupakan suatu kewajiban yang berat; harus memiliki cukup idealisme.

3. Notaris diharapkan dalam menjalankan jabatannya selaku pejabat umum yang berwenang dalam pembuatan akta otentik, mampu memahami dan melaksanakan ketentuan-ketentuan Peraturan Jabatan Notaris dan Undang-Undang Nomor 2 Tahun 2014 tentang Jabatan Notaris sebagai pedoman dalam melaksanakan profesi Notaris.

4. Hendaknya Majelis Pengawas yang mengawasi Notaris dalam menjalankan tugas dan jabatannya adalah pengawas yang memiliki pengetahuan dan mengerti tentang kenotariatan khususnya dalam pembuatan akta otentik dan juga memiliki integritas moral yang tinggi.

5. Dengan adanya perlindungan hukum dilaksanakan terhadap Notaris, hendaknya bisa menjadi seorang pejabat umum yang profesional dalam jabatannya khususnya dalam pembuatan akta yang bersifat otentik dan melaksanakan tugas dan jabatannya dengan memperhatikan nilai luhur, martabat dan etika serta mematuhi peraturan perundang-undangan yang berlaku.

6. Pengurus organisasi INI diharapkan lebih intensif dalam mengadakan pertemuan dengan melibatkan unsur MPD guna membahas masalahmasalah seputar pelaksanaan jabatan Notaris khususnya yang berkaitan dengan kode etik dan undang-undang, sehingga para notaris lebih memahami dan mengerti tentang tugas jabatannya berkaitan dengan Kode Etik dan Undang-Undang.

\section{DAFTAR PUSTAKA}

Abdul Ghofur Anshori, "Lembaga Kenotariatan Indonesia, Prespektif Hukum dan Etika", (Yogyakarta : UII Press, 2009)

Munir Fuady, "Profesi Mulia (Etika Profesi Hukum bagi Hakim, Jaksa, Advokat, Notaris, Kurator dan Pengurus)", (Bandung: PT. Citra Aditya Bakti, 2005)

Hasil Wawancara dengan Notaris Ratnawati.,S.H Notaris Senior Kabupaten Purbalingga, di Purbalingga, Tanggal 1 Agustus 2016

Hasil Wawancara dengan Notaris Ratnawati,S.H Notaris Senior Kabupaten Purbalingga, di Purbalingga, Tanggal 1 Agustus 2016

Hasil Wawancara dengan Tajuddin Nasution,S.H Ketua Majelis Pengawas Daerah Notaris Kabupaten Purbalingga, di Purbalingga, Tanggal 2 Agustus 2016

G.H.S Lumban Tobing, Peraturan Jabatan Notaris, Cet.5, ( Jakarta: Airlangga, 1999 ), h.301

Wawancara Agung Diharto, Notaris dan Ketua INI di Kabupaten Purbalingga, Pada Tanggal 2 Agustus 2016 